\title{
Vietnamese in Moscow: irregular migration and development in South-South corridors
}

Edition 8, 2021

Associate Professor Lan Anh Hoang

DOI: 10.37839/MAR2652-550X8.15

Scholarly research on migration to post-Soviet Russia is remarkably scant despite the fact that the country has been listed by the International Organization for Migration as the second most important destination in the world and one of the ten largest sources of remittances since 2005. As of 2019, there were 11.6 million international migrants in Russia, the majority of whom were citizens of the Commonwealth of Independent States (CIS). This official figure, however, excludes millions of undocumented migrants, who are believed to exceed the number of documented migrants. Large numbers of non-CIS migrants in Russia come from China and Vietnam, Russia's former socialist allies, a legacy of Cold War geopolitics.

In the current migration and development debates, the bias toward South-North migration has resulted in an important knowledge gap relating to those who move within the corridors of the Global South where migration is aided by porous borders and large shadow economies, but fraught with risks and vulnerabilities.

In this article, I draw on ethnographic research on Vietnamese migrants in Moscow from 2013 to 2016 to provide original insights into processes of mobility and change in Russia which continues to grapple with the incongruence between Soviet-style governmentality of immigration and new structures and demands of the post-Soviet capitalist economy.

Before 1990, when the Soviet Union began to disintegrate, migration from Vietnam 
to the Soviet Union was only possible through official education and contract labour programs, the latter of which was part of post-war Vietnam's obligations to the Council for Mutual Economic Assistance. Migrants were first sent to the Soviet Union for higher education and vocational training in the mid-1950s and then for contract work during the 1980s. Because an opportunity to migrate overseas for work or education during the Cold War was treated as a reward for loyalty to the communist regime, Vietnamese migrants to the Soviet Union were mostly from families of war martyrs, war veterans, and state employees in the North and North Central. Contract workers were employed in a range of industries including construction, mechanics, textiles, garment production, agriculture, health care, and education. Shortly before the Soviet Union's disintegration, about 100,000 Vietnamese were working in Russia.

By late 1991, most of the students and workers had been repatriated, but many subsequently found their way back to Russia, often bringing with them families and friends, leading to chain migration from their places of origin. With only a few exceptions, my research participants had all migrated to Russia with the assistance, and sometimes financial support, of family members or fellow villagers. New (and young) migrants typically work for their relatives for a few years, with little or no pay, to repay the travel debt and learn the trade, often with the hope that the free labor will eventually be recompensed with assistance when they set up their own business. Older migrants tend to migrate without dependants in the first instance and send for their partners once they have settled in, leaving children behind with the extended family in Vietnam. 


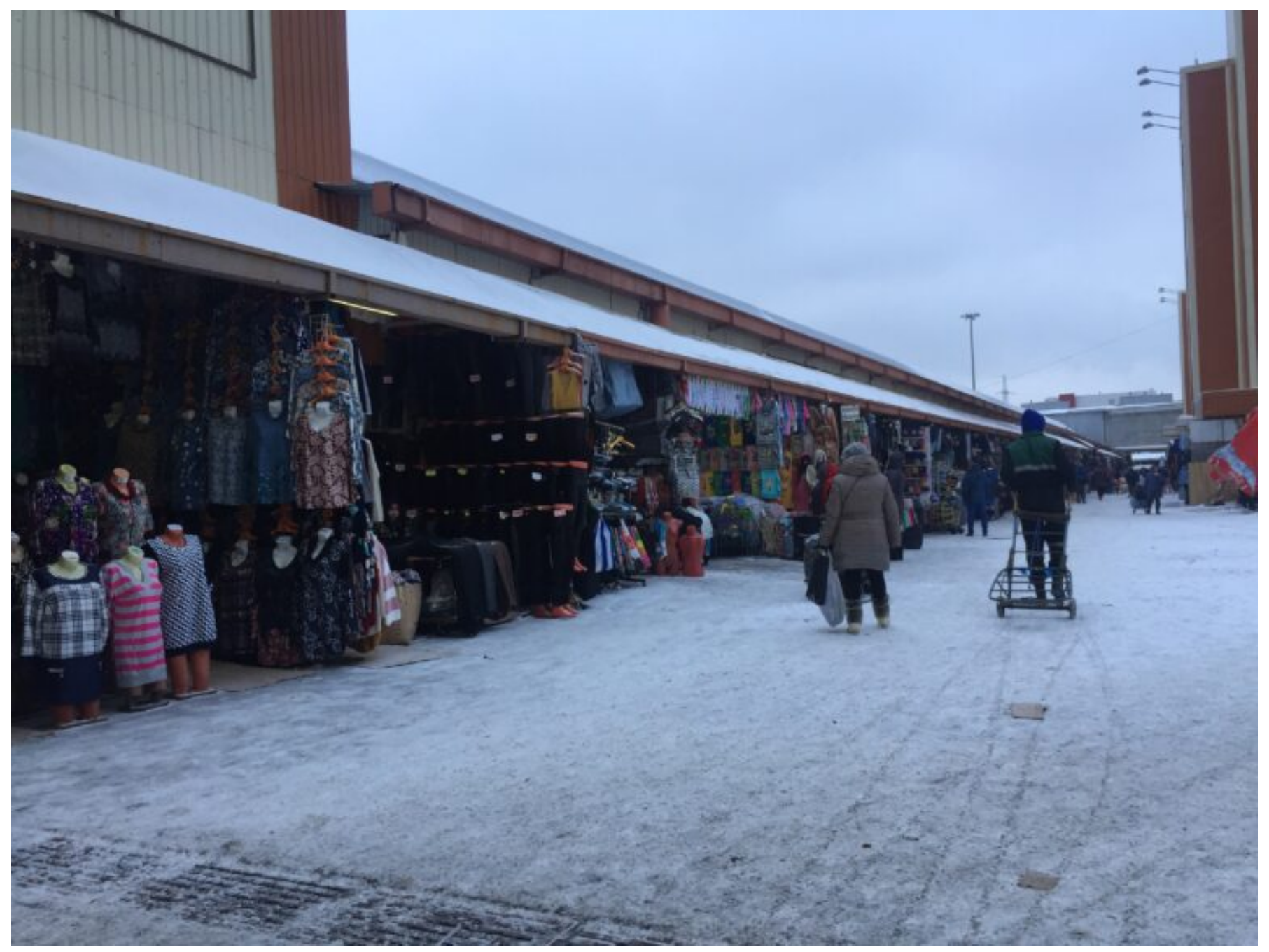

Sadovod market, stores on the eastern side of the pavilions, November 2016, Moscow. Photo by Lan Anh Hoang.

Northern and North Central Vietnam, where most Vietnamese migrants in Russia hail from, have been plagued by under- and unemployment since the launch of Đôi mới economic reforms in 1986, which moved Vietnam from a command economy to the so-called 'socialist-oriented market economy.' Although the extreme poverty rate has fallen remarkably from 50 percent in the early 1990s to two percent as of 2018, the reforms have disproportionately benefited those with education, skills, and connections with the communist regime. The abolition of state subsidies in agricultural production, education, healthcare, and many other social benefits is accompanied by high inflation rates, low productivity, and underemployment. Most 
pockets of poverty remain in rural areas, where transnational migration for work has become one of the most viable livelihood strategies. With limited education, language skills, and economic resources, rural residents have two main options: contract labour migration to other Asian countries through formal channels; or irregular migration to post-communist countries in Eastern Europe, including Russia.

Migration under formal labour export programs is generally less risky but requires a significant financial investment which potentially leads them into debt traps and consequently labour exploitation and abuse. Before the COVID-19 pandemic, there were about 500,000 Vietnamese contract workers in Taiwan, Japan, Malaysia, South Korea, the Middle East and North Africa. They typically migrate on two- or threeyear contracts, with men concentrated in construction sites, farms, and industrial estates and women in manufacturing industries and domestic and care services. While irregular migrants in Russia do not face the same restrictions as contract workers, their migration is also controlled by complex and highly exploitative transnational brokerage networks.

Today, Vietnamese migrants often travel to post-Soviet Russia with a student or tourist visa and then overstay their original visa or, less often, legalise their sojourn by obtaining a short-term work permit or dependant visa through commercial intermediaries. Russia, with one of the largest shadow economies in the world, is an ideal haven for low-skilled, irregular migrants who would not be able to find the same economic opportunities in a more tightly regulated economy. Because Vietnamese migration to post-Soviet Russia is largely undocumented there are no reliable statistics and estimates vary widely. In 2007, the Vietnamese government estimated that there were between 80,000 and 100,000 Vietnamese nationals in Russia but another study suggests that figure to be 150,000.

Vietnamese migrants in Russia mostly earn their living from market trade, which started with the illicit 'suitcase' trade in the early 1980s, when they smuggled Chinese or Japanese merchandise in travel luggage from Vietnam into the Soviet 
Union and shipped highly valued Soviet-made products back home. These activities continued in a discreet and ad hoc manner until the mid-1990s, when profit making was no longer considered illegal, before moving to open markets in Moscow's outer suburbs. The 'golden age' of unregulated trade and commerce was a common feature of European post-socialist economies in the 1990s when 'one could sell anything and turn a profit'.

Because of their irregular status, limited Russian language skills, and racial discrimination in the formal economy, migrants' attempts to access formal employment opportunities beyond the shadow economy are most likely to be futile, even if they have received higher education degrees from Russian universities.

\section{Russia's governmentality of immigration}

Russia's immigration policies are a site of tension between an acute need for migrant labour and deep anti-immigrant sentiment in the public. Migration securitisation since the turn of the millennium led to the reorientation of the Federal Migration Service's (FMS) mandate from humanitarian assistance for refugees and displaced people to immigration control and policing, which allows the FMS and police officers to conduct random document checks in public places and private homes. The post-Soviet state's ambivalent attitude to and arbitrary treatment of foreign migrants render them vulnerable to police harassment, extortion, and protection racketeering as well as xenophobic violence and opportunistic crime. It has also given rise to an extensive and sophisticated brokerage industry which shapes and sustains migrants' lives on the margins of Russian society.

As Vietnamese migrants' lives are usually restricted to the safe bounds of their ethnic bubble, brokers serve as vital bridges between them and Russian society, assisting them in navigating Russia's notoriously cumbersome bureaucratic system and enabling them to move out of their 'bubble' when it becomes unavoidable due to serious health problems, childbirth, litigation, or the need to enrol children in a local 
school. The treacherous and exploitative nature of the brokerage industry, however, further entrenches migrants' vulnerabilities and precarities. For example, a work permit or dependant visa, both of which are usually valid for three years, cost about US $\$ 3,500$ at the time of my fieldwork in 2014-a small fortune for most migrants. In many situations, such a document does not guarantee legal status because migrants are neither sure of their authenticity nor able to demonstrate that they are currently living at the registered address, which is mandatory for Russian residents.

Only CIS citizens are eligible to apply for a work patent (as the Russian government calls them) that does not require a corporate sponsor and allows its holder to work for any employer in the region for which the patent has been issued. This restriction leaves millions of non-CIS migrants stranded in the shadow economy. Russia's exclusionary citizenship law renders virtually every Vietnamese migrant ineligible for naturalisation. The 2002 Federal Law on citizenship allows foreign citizens to apply for Russian citizenship only after five years of 'uninterrupted legal stay' in Russia. 'Legal stay' means the possession of a valid work permit or permanent residency as well as voluntary health insurance, a taxpayer identification number, and a pension identification number.

Migrants' sense of vulnerability and racial inferiority is further reinforced by the anti-immigrant discourse propagated by Russian mainstream media, which routinely associate irregular migration with crime, fraud, and violence. An article on the stateowned ITAR-TASS, for example, reports the number of 'illegal' migrants in Russia as three million in 2014, but adds the highlighted subheading 'Migrants committed 47,000 crimes last year.' The same article also cites a report commissioned by the Institute of National Strategy that highlights 'three main characteristics of migrants since 2000,' including cultural backwardness, poor skills, and a demographic imbalance in their areas of residence. Foreign migrants are represented as a problem, criminals, and a security risk. In their public addresses, the country's top leaders actively reinforce the image of foreign migrants as dangerous terrorists or criminals who bring diseases, violence, and social problems to Russia. Such a negative portrayal of foreign migrants serves to justify stricter immigration policies 
and even the use of force in anti-immigration campaigns.

Anti-immigrant sentiment is particularly directed against the racial 'others' from non-European parts of the former Soviet Union, Asia and Africa. Chinese and Vietnamese migrants are more likely than other ethnic groups to be targeted by xenophobic gangs because of their distinct racial and cultural backgrounds and limited Russian language skills, which is believed by many Russians to threaten the cultural identity of local populations and the social harmony of Russian society. Although the number of racist attacks has decreased significantly in the past decade (72 attacks reported in 2016, compared with 515 in 2008), there is no solid evidence showing that xenophobic sentiments have abated.

Russia's exclusionary immigration policies enable an extremely exploitative market regime in which unlawful practices are used with impunity, including the use of force to discipline rule-breakers. While the store rental rate varied widely among the three largest markets of Moscow where I conducted my fieldwork-ranging from RUB600,000-700,000 (USD17,000-20,000) at Liublino (Люблино, officially Торгово-ярмарочный комплекс Москва) to RUB330,000 to 600,000 at Sadovod (Садовод) and RUB20,000 to RUB35,000 at Yuzhnyie Vorota (Южные ворота) - it is invariably exploitative relative to the income that traders at the respective market can earn. Stores must be kept open long hours every day rain or shine if traders are to sustain the rent, labour costs, and daily living expenses. As time becomes a currency, migrants' social lives are condensed into casual chats with fellow traders during the day at the market, celebrations of life milestones are forgone, and care and guardianship of their children are outsourced to the extended family (if they live in Vietnam) or commercial intermediaries (if they live in Russia), which has devastating consequences in many situations.

As market trade is considered women's domain in Vietnamese society, the sense of loss and sacrifice is felt more strongly by my female interlocutors who are responsible for the day-to-day running of the business while striving to fulfil their traditionally ascribed care duties from afar. When I remarked that I saw only men lounging at 
restaurants and cafés on the market compound while women always hustled about, getting things done, 46-year-old garment factory owner named Thảo laughed 'We (women) don't live here. We are here to make money.' Although men are no less vulnerable than women in the exploitative shadow economy, women are those who bear the brunt of parenting failures, marital disruptions, and family breakdowns, to which the transnationally split family is particularly susceptible.

\section{Migrants' immobilities}

Research on contract migrant workers in Asia, including my own, shows that migrants' immobilities and vulnerabilities are largely attributable to the restrictive migration policies of the host country that do not allow them to bring dependants, apply for permanent residency or citizenship, and exercise autonomy and bargaining power in labour relations. In Russia, it is the lax migration regime that immobilises migrants. Although their spatial immobility is self-enforced in most situations, it is migrants' rational response to the vulnerabilities engendered by Russia's migration regime that allows them to enter the country and stay with ease but turns a blind eye to their predicaments in the shadow economy.

Vietnamese migrants cluster together in 'ethnic enclaves' in the vicinity of suburban wholesale markets, avoid contact with non-Vietnamese wherever possible, and reduce their movement to a bare minimum. Due to the high demand for accommodation near the market, they must put up with basic living conditions in rented apartments or overcrowded migrant hostels, where up to 20 people share a room. Squalid living quarters become breeding grounds for both disease and conflict, giving parents no privacy and children no play or study space. Confined to their ethnic bubble and the daily home-market grind, migrants have limited interpersonal contact with local populations, which further perpetuates distorted stereotypes and entrenches their irrational fears about one another. To my research participants, dangers seem to be lurking around every street corner. Even the daily trip to work is fraught with anxieties and fears, as described here by a 47-year-old trader named 
Hạnh 'I get butterflies in my stomach as soon as I leave home. It's already bad luck if I bump into police, but it'd be worse if it's hooligans [skinhead gangs].'

Although their lives are regulated by same migration regime, how Vietnamese migrants experience it largely depends on the economic and cultural capital that they possess. A valid document such as a work permit or a dependent visa may not keep them immune from police harassment and extortion, but can help avoid the worst outcomes such as detention and deportation when intercepted by Russian police. However, given its prohibitive cost, only a fraction of the Vietnamese migrants in my study could afford such a document. Those fortunate enough to have one still avoid venturing outside their home-market route, if possible, because of the risk of police entrapment and interception on public transport. Unable to communicate effectively in Russian, they risk being harassed, threatened, or even detained by Russian police. The relative freedom of movement is enjoyed by only a handful of well-to-do brokers and business owners who can afford private transport and valid migration documents, as well bribes for police officers if necessary.

Migrants' precarious, transient, and isolated existence on the margins of society explains the importance of the transnational ties they maintain between Russia and Vietnam. Very few people that I met during fieldwork aspired to settle down permanently in Russia. Unable to predict what tomorrow will bring, they make every effort to scrimp and save, minimising their commitments in Russia, so that they can pack their bags and leave anytime. Children are often sent to the extended family in Vietnam after birth or before they reach the school age so that their educational stability can be ensured. The parent-child separation stretches throughout the latter's childhood in many situations, with damaging consequences for both marital and intergenerational relationships. As Russia is generally seen as a phase in one's life, not a place fit for permanent settlement, migrants invest any savings they have in real estate properties in the homeland. The most common way to greet someone a migrant has not seen for a long time, I observe, is to ask the person: 'How many plots of land did you buy last year?' For my research participants, one's economic success is measured by the total value of his or her real estate properties in Vietnam 
and not by the scale and revenue of their business or the kind of lifestyle they have in Russia.

Vietnamese migrants' expressions of belonging and aspirations for the future (beyond Russia) are best captured by the notion of the transnational social field in the migration scholarship, which refers to 'a set of multiple interlocking networks of cross-border social relationships through which ideas, practices, and resources are unequally exchanged, organised, and transformed.' This concept offers a powerful framework for understanding the array of social relations linking those who move and those who stay behind and deepens our understanding of the migrationdevelopment nexus. Migration is often assumed to have the power to open up new transnational social fields and expand existing ones. My research in Russia, however, shows that migrants' social fields may be circumscribed, rather than expanded, as their immobilities and vulnerabilities become normalised and are even legally sanctioned by the state.

Here, we observe a paradox whereby migrants' immobilities in Russia enable the mobilities of their non-migrant children in Vietnam. As I have discussed in detail elsewhere, migrant parents plough significant amounts of savings into their children's education and career back home, hoping to move them up the social ladder in Vietnamese society. Transnational migration as well as identity and belonging are classed and raced experiences deeply embedded in the political economy of migration. Globalisation has not led to the deterritorialisation of the nation-state, rather the nation-state retains its power in shaping migrants' transnational social fields, dictating the terms of their engagement with cross-border processes and networks.

Main image: Vietnamese workers at an illegal garment factory (deidentified), May 2014, Moscow Oblast. Photo by Lan Anh Hoang. 